\title{
Early English Receipts for Painting , Gilding, \&c.
}

\section{T. Wright}

To cite this article: T. Wright (1844) Early English Receipts for Painting , Gilding, \&c., Archaeological Journal, 1:1, 64-66, DOI: 10.1080/00665983.1844.10850538

To link to this article: http://dx.doi.org/10.1080/00665983.1844.10850538

曲 Published online: 10 Jul 2014.

Submit your article to this journal ¿

Q View related articles $₫$ 


\title{
Origínal 有ocuments,
}

\author{
ILLUSTRATING THE ARTS \&C. OF THE MIDDLE AGES.
}

EARLY ENGLISH RECEIP'TS FOR PAINTING, GILDING, \&c.

THE old monastic artists frequently inserted in the margins or blank pages of a manuscript, receipts and directions for the different materials and processes connected with their work. These receipts deserve being collected: they are curious illustrations of the progress of art, and they may even afford valuable hints for modern times. The colours used in the Middle Ages were often more brilliant and durable than any we have at present. The following examples of these receipts are furnished by a manuscript in the British Museum, (MS. Harl. No. 2253. fol. 52. $v^{\circ}$.,) written at the beginning of the reign of Edward II., and therefore in, or soon after, 1307.

Vorte make cynoplea. Tac brasyl and seoth in dichwatur ${ }^{b}$ to the halfendel other to the thridde partie, ant seththe tac a ston of chalk, ant mak an hole ithe chalk, as deop ant as muche as thu wenest that thi watur wol gon in, ant heldit therin, ant seththe anon riht quicliche tak a bord other a ston ant keover hit that non eyr ne passe out, ant let hit stonde vorte hit beo colt.

Vorte temprene asure. zef thin asure is fin, tak gumme arabuk i-noh, ant cast into a standys ${ }^{c}$ with cler watur vorte hit beo i-molten, ant seththe cast thereof into thin asure, ant sture ham togedere, ant zef ther beth bobeles theron, tac a lutel ere-wax ant pute therin, ant thenne writ. Et ne grynt

a A bright colour, apparently red, in Medieval Latin called sinopis, which Ducange pretends was green. The lexicographer quotes the following passage from a life of St. Willelm, in the Acta Sanctorum-"Qui enim solebat paulo ante in palatiis degere, auro radiantibus ac depictis sinopide." [Since this was in type, I have met with the following more definite account of this colour (which appears to have been used very extensively) in Whethamstede's Granarium, MS. Cotton, Nero c. vi. folio. 156, ro. "Sinopim, colorem videlicet illum cujus tres sunt species, videlicet rubea, subrubea, et inter has media, invenerunt primitus, ut scribit Ysidorus, viri regionis Ponticæ in urbe eorum quam solent ipsi Sinopem vocitare."]

b Room for three or four words is here left blank in the MS. This is the earliest instance I have yet met with in English of the word brasil, which signified a kind of wood, from which perhaps the name was afterwards given to the country. See Mr. Way's note on this word in the Promptorium. In Latin documents written on the Continent the word is found as early as the twelfth century.

e A wine-vessel.

d This word et occurs frequently at the commencement of a phrase, apparently written for and. 
thu nout thin asure nevermore. Et fef hit nis noht fin, tac i-tempret gleyr, ant cast therto, ant let hit stonden ant resten vorte al the asure beo i-vallen adoun to grounde. Et bote thu seo hit fin, cast out the gleyr softeleche, ant cast therto more gleyr, ant wash hit eft sonus ithe selve maner. Et whan hit is wel i-puret ant the gleyr i-hald out clene, thenne cast therto thi gummet-water, ant writ, as ic seyde er.

Vorte make grasgrene. Tac verdigres ant grynt hit, ant cast hit into thin staundys, ant cast therto the fineste wort that thu myht i-finden, ant sture togedere ant writ.

Vorte maken another maner grene. Tac jus of a rotet appel, ant tempre thi verdigris mid, ant wryt.

zet for gaudegrene ${ }^{e}$. Tac peniwort other gladene, whether thu wolte of the two erbes, ant tempre thi verdigres, ant writ.

Vorte couche ${ }^{f}$ selverfoyle. Tac gumme arabuk, ant cast hit into tempret gleyr vorte hit beo i-molten, ant seththe tac chalk ant grynt hit as smal as thu myht, ant tempre hit with thilke water that is i-cleopet gleyr as thikke as thu wolt leggen hit with a pinsel, other with what thu wolt. Et ther as hit is i-leyd let hit resten that hit beo druye, ant thenne tac thi selverfoyl ant ley theron, ant zef hit is i-druyet to druye ethe theruppon with thi breth, ant hit wol moysten azeyn, ant thenne hit wol cachen the foyl fast ant stike wel the betere, ant wit an hare tayl thac $\mathrm{g}$ hit to, ant seththe tac an houndus tooh ${ }^{\mathbf{b}}$ ant vasne in a stikkes ende, ant robbe uppon thi lettre, other uppon whet other thing hit beo, ant that that hath the sise schal stunte stylle, ant that that nat nout the sise wol awey.

Ithe selve maner mac the sise to goldfoyl, save tac a lutel radel ant grynt to thin asise, vorte loosen is colour, bi resun of the goldfoyl, ant so vorth as I seyde er.

Vorte maken iren as hart as stel. Tac arguli, a thing that deyares deyet with, ant grint hit smal, ant seththe tac a wollene clout, ant couche thi poudre theron as brod as hit wol. Cluppe the egge of thi lomek, other of whet thu wolt, and seththe ley the egge ithe middel of the poudre, ant seththe wint thi clout faste abouten thi lome, ant pute hit into the fure that hit beo gled ${ }^{1}$ red, ant thenne anon cast hit into water.

Vorte maken blankplum ${ }^{m}$. Tac a vessel of eorthe, other of treo, of a galun, other more other lasse, cheos thu. Et seththe bore holes acros ithe

e The Promptorium explains "Gawdy gren, subviridis."

To couche, is to lay down, here used technically for to lay or fasten the silverfoil or goldfoil on the vellum.

$\mathrm{g}$ To thac, is to pat it.

h I believe the dog's tooth is still used among book-binders to burnish gold on paper.

It appears, by the explanation the writer gives, that this was a word of only very restricted use-" a thing that dyers dye with." Chaucer (Cant. T. 16280) says the Alchemist used, among other things,-

Cley made with hors and mannes here, and oile Of tartre, alum, glas, berme, wort, and argoile.

I doubt if Tyrwhitt has rightly interpreted it potter's clay.

k Lome, an instrument; egge of thi lome, edge of thy instrument or tool.

1 Gled, a spark of fire; gled red, red hot.

m White-lead. 
.iij. sides, that is to siggen, the verste .iiij. holes an .v. unchun, other more other lasse, from the grount to the mesure of thi vessel that is. Et seththe an .iij. unchun other more herre other .iiij. holes acros, and so herre ant herre vorte thu come to the ovemoste ende, whether the vessel beo more other lasse. Et seththe tac led ant melt hit. Et zef hit nis nout fin ant clene i-noh, cast hit into clene water, ant bote hit beo fin ant clene thenne, eft sone meltit ant cast hit into watur. Et so pure hit vorte hit beo fin ant clene i-noh. Et seththe meltit azeyn, ant cast hit into an empti bacyn, other into whet vessel thu wolt of bras, that hit vleote ${ }^{\mathbf{D}}$ abrod vorte beo thunne. Et zef hit nis nout thunne i-noh, tac an homur ant bet hit as thunne as thu myht. Et seththen tac stikken ant pute acros ithe .iij. holes, in everuch degre herre ant herre. Et uppon everuch stikke honge of that thunne led, as thicke as thu miht, from gre to gre, so that no degre touche other. Et seththe tac vinegre ant held into the vessel i-noh, so that the nethemoste led ne touche nout the vinegre. Et seththe tac a ston, other a bord, that wol kevere the vessel, ant clos hit above wel ant faste. Et seththe tac fin cley ant good, ant dute al the vessel that non eyr ne go out, bothen the holes ant eken above ryht wel. Et thenne tac thi vessel ant sete hit into horsse dunge depe, bi the space of ix. niht, other more, ant thenne tac up thi vessel, ant unclosit above, ant zef thu findest eni led uppon the stikkes undefizet ${ }^{\circ}$, hit is in defaute of to lutel vinegre; ant zef thi led is defizet al ant findest vinegre ithe grounde, thenne hit is wel, thenne held out softeliche that vinegre, ant tac up thi blankplum, ant do therwith whet thu wolt. Ant thah thu finde eni led, as ic sayde er, undefizet, kep hit that another time, that thu wolle make more.

T. WRIGHT.

n Flow.

o Defiz̨en, to dissolve ; defį̄et, dissolved ; undefizet, undissolved. 